\title{
Egészségkockázati mutatók alakulása az iskolások körében
}

\section{Összefoglalás:}

A társadalom az egyének egészségtudatosságát több módon is befolyásolhatja. A fiatalkori magatartásformák kialakulásában a társas kapcsolati háló az egyik legfontosabb motivációs háttértényező. A fiatalok esetében a szülők és a kortársakból álló baráti csoportok jelentik a legfontosabb társas kapcsolatokat. . Több kutatás, felmérés is foglalkozik közvetlenül a fiatalok egészséggel kapcsolatos magatartásával, de közvetetten is szerezhetünk információt az egészségkockázati mutatókról. Ilyen forrás az évenkénti kötelező iskola-egészségügyi jelentés. Az iskola-egészségügyi jelentés a legnagyobb olyan évenkénti, szakemberek által végzett adatgyűjtés, amely részletes adatokat szolgáltat a 8-18 éves gyermekek egészségi állapotáról, többek között információt ad 34 meghatározott betegség előfordulásáról, többek közt az elhízás gyakoriságáról is. Az adatgyűjtést a 76/2004. (VIII.19.) ESzCsM rendelet számú jogszabály alapján kötelező, a jelentés címzettje az Országos Tisztifőorvos. A jelentésből származó egészségkockázati mutatók alakulása és annak megismerése egyfajta jövőképet ad egészségtudatos magatartás alakulásáról. Továbbá információt nyújt arról, hogy az iskolaorvosok és iskolai védőnők milyen rendszerességgel, milyen témában tartanak prevenciós előadásokat, foglalkozásokat.

Fontos, hogy az adatgyűjtés eredményeinek ismeretében az egészségkockázati mutatók gyakoriságát csökkentsük, azáltal, hogy a befolyásolható tényezőket megpróbáljuk megváltoztatni. Lehetséges eszköze ennek a Teljeskörü Iskolai Egészségfejlesztés (TIE), amelynek célja az egészség megőrzése, fejlesztése, a betegségek hatékony megelőzése, az egészségtudatos magatartás és az egészségismereten alapuló szemléletet kialakítása. Előnye, hogy nem csak egy beavatkozási területre koncentrál, hanem mindegyik fö egészség-kockázati tényezőt befolyásolja. Az iskola mindennapi életében folyamatosan jelen van és az egészségfejlesztést megvalósító iskola minden tanulója részt vesz benne. De iskolán kívül, lakossági szintéren, a családokat együtt bevonva az Egészségfejlesztési Irodák segítségét kérve is megvalósíthatók a gyerekek egészségét célzó prevenciós programok.

Kulcsszavak: egészségkockázat, egészségfejlesztés, elhízás, egészségmagatartás 